
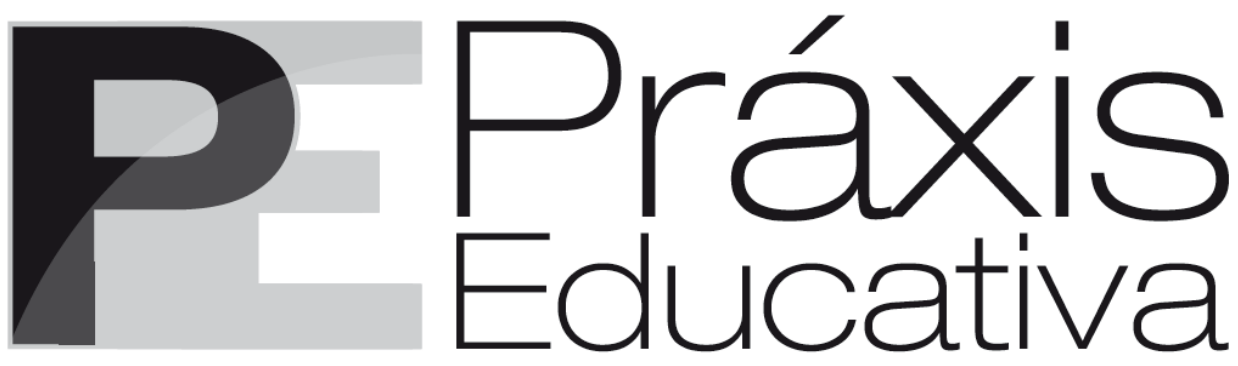

ISSN 1809-4309 (Versão online) DOI: 10.5212/PraxEduc.v.12i2.0019

\title{
A criança como ator social - críticas, réplicas e desafios teóricos e empíricos ${ }^{*}$ \\ The child as a social actor - critiques, counter-arguments and theoretical and empirical challenges
}

\section{E1 niño como actor social - críticas, réplicas y desafíos teóricos y empíricos}

Rita de C. Marchi**

\begin{abstract}
Resumo: Este artigo discute desafios teóricos e empíricos da ideia da criança como ator social, presente nos estudos sociais da infância, por meio de análise das críticas feitas ao conceito por autores pertencentes ao campo e autores externos a ele. São também discutidas réplicas em sua defesa. As críticas e as réplicas estendem-se em um espaço de 10 anos (2005 a 2015). O conceito de ator social é situado, neste artigo, no viés da teoria weberiana e no quadro da "dupla hermenêutica" como "modelo de reflexividade" nas Ciências Sociais, de A. Giddens: teorizar sobre o fenômeno implica envolver-se no seu processo contemporâneo de desconstrução/reconstrução. Assim, os riscos ou as consequências do que a ciência afirma sobre as crianças recairão sobre elas próprias e sobre as formas sociais de sua compreensão. Nesse sentido é que se compreende que devem ser analisados os alertas feitos ao discurso especialista (tanto o discurso crítico quanto o de defesa crítica do conceito).
\end{abstract}

Palavras-chave: Criança. Ator social. Estudos sociais da infância.

Abstract: This paper discusses the theoretical and empirical challenges of the idea of the child as a social actor, present in the social studies of childhood, through the analysis of criticisms made to the concept by authors belonging to the field and authors external to it. Counter-arguments are also discussed in its defense. The criticisms and counter-arguments extend over a period of 10 years (2005 to 2015). The concept of social actor is situated in this paper in the bias of the weberian theory and in the framework of the 'double hermeneutic' as A. Giddens's 'model of reflexivity' in social sciences: theorizing about the phenomenon implies being involved in its contemporary process of deconstruction/reconstruction. Thus, the risks or consequences of what science claims about children will fall on themselves and on the social forms of their understanding. In this sense, it is understood that the alerts made to the specialist discourse (both the critical discourse and the critical defense of the concept) must be analyzed.

Keywords: Child. Social actor. Social studies of childhood.

\footnotetext{
* Este artigo é decorrente de estágio pós-doutoral na área dos estudos da criança, realizado no Instituto de Educação da Universidade do Minho, com a colaboração do Prof. Dr. Manuel Sarmento. O estágio pós-doutoral teve financiamento da CAPES e da Universidade Regional de Blumenau. Aos indivíduos e às instituições que possibilitaram essa realização, o meu agradecimento.

** Professora do Programa de Pós-Graduação em Educação (PPGE/ME) e do Curso de Ciências Sociais da Universidade Regional de Blumenau (FURB). E-mail: <rt.mc@bol.com.br>.
}

Práxis Educativa, Ponta Grossa, v. 12, n. 2, p. 617-637, maio/ago. 2017 Disponível em: <http://www.revistas2.uepg.br/index.php/praxiseducativa > 
Resumen: En este artículo se discuten los desafíos teóricos y empíricos de la idea del niño como actor social, presente en los estudios sociales de la infancia, por medio del análisis de las críticas hechas al concepto por autores pertenecientes al área y autores externos a ella. Son también debatidas réplicas en su defensa. Las críticas y las réplicas se extienden en un espacio de 10 años (2005 y 2015). El concepto de actor social se lee, en este artículo, a través de la teoría weberiana y en el marco de "doble hermenéutica" como "modelo de reflexividad" en las Ciencias Sociales, propuesto por A. Giddens: teorizar sobre el fenómeno implica participar en su proceso contemporáneo de deconstrucción/ reconstrucción. Así, los riesgos o las consecuencias de lo que la ciencia afirma de los niños recaerán sobre ellos mismos y sobre las formas sociales de su comprensión. En este sentido es que se comprende que deben ser analizados los alertas hechos al discurso crítico especialista (tanto el discurso crítico como el de defensa crítica del concepto).

Palabras clave: Niño. Actor social. Estudios sociales de la infancia.

\section{Introdução}

Atualmente, a ideia de que as crianças são atores sociais é já genericamente aceita pelas diversas ciências sociais. No entanto, algumas críticas são endereçadas às formas como essa figura teórica, ao vulgarizar-se ou ser adotada de forma não reflexiva, tanto nos estudos quanto nas práticas sociais, corre o risco de encerrar uma "nova ortodoxia" ou de, em um enfoque demasiado simplista e unicamente "centrado na criança", tornar-se um "slogan vazio" (BUCKINGHAM, 2002).

Bühler-Niederberger (2006) alertou para o risco da "fascinação pelas competências" da criança e pela construção de suas "culturas infantis" tornarem-se uma espécie de "romantismo clandestino da ciência", a ignorar o fato de que nenhuma outra idade da vida é tão codificada e estruturada pelos esforços de regular o acesso às posições da sociedade. Contudo, talvez a crítica mais contundente seja a de Prout (2005), com a constatação de que os pressupostos sociológicos sobre a modernidade chegaram já tardiamente e sem valor conceitual à Sociologia da Infância. Este seria o caso da ideia da criança como ator social e da infância como estrutura, pelo fato de reproduzirem dicotomias sociológicas clássicas que têm se mostrado incapazes de dar conta do caráter instável, ambíguo e flexível dos fenômenos sociais na modernidade tardia. Oswell (2013), concordando com a crítica de Prout, também considera necessário fugir à hipostasia dos polos antinômicos (agência $x$ estrutura) para poder vê-los como reflexivamente entrelaçados, especialmente no que diz respeito à agência das crianças.

Este artigo discute, assim, a ideia da criança como ator social presente nos estudos sociais da infância. Apresento críticas feitas ao conceito, assim como réplicas em sua defesa, tanto por autores pertencentes ao campo quanto por autores externos a ele. As críticas e suas réplicas se estendem em um espaço de 10 anos (2005 a 2015).

As críticas ao conceito de "agência da criança" ou da "criança como ator social" podem ser assim sintetizadas:

- O conceito não é analisado nas pesquisas, mas tomado como fato ontológico, naturalizado (PROUT, 2005; KING, 2007; LANCY, 2012).

- O conceito é etnocêntrico e tem viés de classe porque enquadra apenas a vida da criança "individualizada" (com direito a direitos) dos países europeus (do "Norte" ou do denominado "mundo Maioritário"), não estando disponível ou presente entre crianças das sociedades tradicionais ou crianças de classes desfavorecidas nos países do Sul (ou do

Práxis Educativa, Ponta Grossa, v. 12, n. 2, p. 617-637, maio/ago. 2017 Disponível em: <http://www.revistas2.uepg.br/index.php/praxiseducativa > 
"Mundo Minoritário")" (BÜHLER-NIEDERBERGER; KRIEKEN, 2008; LANCY, 2012).

- O conceito é, assim, um "rótulo' (uma espécie de passaporte) para financiamento de pesquisas ou de pertencimento ao campo dos estudos sociais da infância, um "dogma" científico (LANCY, 2012) e/ou uma espécie de "defesa" ("advocacia") da ampliação e da realização dos direitos das crianças (KING, 2007; BÜHLER-NIEDERBERGER, 2010; LANCY, 2012).

Este artigo é também uma espécie de resposta (um tanto tardia) a uma pergunta feita no VII Seminário de Pesquisa em Educação da Região Sul (ANPEDSUL) durante uma comunicação oral sobre o "ofício de criança" e o "ofício de aluno" no quadro das relações entre a Sociologia da Educação e a (nova) Sociologia da Infância (MARCHI, 2010).

A pergunta era se, afinal de contas, o conceito de "ator social" agora atribuído às crianças pelos sociólogos da infância tinha origem no conceito de "ação social" de Max Weber. O autor da pergunta afirmou nunca ter conseguido obter essa resposta nos textos onde a ideia da criançaator se fazia presente. A pergunta surpreendeu pelo fato de fazer-me perceber que, em verdade, eu também nunca havia visto, em textos da Sociologia da Infância, estabelecida a relação entre a teoria weberiana e o princípio da criança como ator social.

No entanto, no meu entender, não pode ser outra a origem do conceito. Assim, embora fosse interessante saber por que - para além de sua "obviedade" - a relação entre o princípio da criança ator e o conceito weberiano de ação social nunca ser estabelecida nos textos, não é esse o objetivo deste artigo. O objetivo é tentar responder, enfim, de forma mais pontual, a pergunta que me foi feita há anos, também porque nesses anos entre a pergunta e a presente resposta vi crescer em mim (e em outros autores, como listado anteriormente) uma insatisfação com o uso não esclarecido desse princípio fundante da Sociologia da Infância. Ou seja, pelo fato de que, nos últimos anos, o tema da criança como ator social ou da "agência da criança" tem sido alvo de um debate que, se não pode ser considerado intenso, é, de todo modo, provocador na polêmica que suscita.

Adiantando já ao leitor minha própria compreensão do conceito, eu assumo que considerar a criança como ator social é simplesmente considerar que ela faz parte da cultura, assim como os membros de qualquer outro grupo de idade ("adultos" e "idosos"). Isso significa, de modo mais amplo, simplesmente reconhecer a criança como um ser humano e, portanto, como um ser social. Sendo assim tão simples, o que há, então, paradoxalmente, de tão complexo e polêmico nessa questão?

Para responder a essa pergunta, talvez se devesse retomar a história da emergência da Sociologia da Infância como uma reação à maneira que as Ciências Humanas e Sociais compreendiam a criança e o período da infância até os anos 80 do século XX, o fato de que essa visão estava orientada pela Psicologia do Desenvolvimento (na área das ciências médicas) e o correspondente conceito de socialização (na Sociologia). Entretanto, essa história da desconstrução das ortodoxias pré-sociológicas e naturalizadas que caracterizaram os estudos anteriores sobre a infância (JAMES; JENKS; PROUT, 2000) está já bem documentada por

\footnotetext{
1 Os termos "mundo maioritário" (África, Ásia, América Latina) e “mundo minoritário" (Reino Unido, EUA, Europa, Austrália, Nova Zelândia, Japão e Canadá) são atualmente usados por autores para designar o que era conhecido como "terceiro" e "primeiro" mundo ou, mais recentemente, como Norte e Sul Global (PUNCH, 2016).
} 
autores da Sociologia da Infância ${ }^{2}$, sendo também reconhecida mesmo pelos críticos do princípio da criança ator (KING, 2007; BÜHLER-NIEDERBERGER, 2010; LANCY, 2012).

Assim, basta lembrar que essa história delineia a chamada invisibilidade científica ou epistêmica das crianças e da infância (SARMENTO, 2007) com sua ausência como categorias conceitualmente autônomas no campo científico. Nesse sentido, destaca-se que essa invisibilidade estava diretamente ligada à invisibilidade social das crianças (e da infância) nas sociedades, isto é, o seu lugar "subalterno" na vida social, o seu estatuto de seres incompletos e em socialização ou "em trânsito" para a idade adulta (o que explica sua presença primeira nas ciências médicas, na psicologia e na pedagogia) e, portanto, o seu confinamento aos espaços educativos. As crianças podem ser vistas, dessa forma, como "atores na sombra", isto é, indivíduos a quem não é (ou não era) reconhecido o "poder de agir" (DELALANDE, 2014, p. 2, tradução nossa). ${ }^{3}$

Em outros textos (MARCHI, 2007, 2009), já assinalei o caráter político dessa questão no sentido que Jenks (2002) assinala: a criança não socializada ${ }^{4}$ ameaça colapsar as ordens sociais; assim, no campo teórico essa ameaça foi mitigada pelo arquétipo da criança como proto-adulto e da remoção de sua prática (ação) social pelas teorias da socialização. Às crianças está destinado, então, que fiquem em "suspensão" como membros da sociedade até que sua socialização/educação esteja completa.

\section{Ação e ator social na teoria sociológica}

Retomemos, de início, a definição de Max Weber para "ação social" como sendo toda ação dotada de sentido pelo sujeito que a pratica, mas que sempre leva em conta, em seu desenvolvimento, a ação do outro. Ou seja, o que torna social toda ação individual é o fato de ser uma "resposta" à ação de outro(s) indivíduo(s). Nesse sentido, toda ação social é intersubjetiva e, por ser simbólica ou dotada de sentido por quem a pratica, é também comunicativa, constituindo-se, ao fim e ao cabo, em uma relação social. Aqui se destaca que o sentido que cada ator dá às suas ações na vida em sociedade só pode ser compreendido no quadro do compartilhamento de uma mesma cultura, isto é, de símbolos e de significados que são comuns. Dessa forma, Weber estabelece o método compreensivo ou interpretativo como o adequado à análise sociológica. Isto é, como método adequado à compreensão da "teia de significados" em que o ser humano está enredado e que ele próprio teceu. Weber colocou, então, a ação e o ator social no centro do seu modelo teórico, diferentemente dos outros clássicos da Sociologia (K. Marx e E. Durkheim) cujos modelos teóricos priorizam a análise das estruturas sociais. ${ }^{5}$

A atual ênfase dada pelos sociólogos da infância às crianças como atores sociais precisa, portanto, ser colocada em relação ao fato de que o chamado "consenso ortodoxo", que dominou o mainstream sociológico até a década de 70 do século XX, fez, por muito tempo, com que o estatuto de ator social fosse subestimado mesmo em relação aos indivíduos adultos. Para esse consenso, o comportamento humano (ação social) resultava de forças sociais (estruturas) que os sujeitos não compreendiam nem controlavam (GIDDENS, 1989). Contudo, aquilo que o sociólogo francês Alain Touraine, nos anos de 1980, chamou de "retorno do ator" à teoria social, trouxe de volta ao

\footnotetext{
2 Sirota (2001), Montandon (2001), Sarmento (2007), entre outros.

${ }^{3}$ No original, acteurs dans l'ombre e la puissance d'agir. Todas as traduções feitas do francês e do inglês para o português são de responsabilidade da autora deste artigo e podem ser conferidas nos originais cujas referências completas se encontram na bibliografia final.

${ }^{4}$ Crianças "de rua", fora da escola, "delinquentes", "antissociais", etc.

${ }^{5}$ Embora a ênfase analítica de Marx e Durkheim esteja na força das estruturas sociais, para o primeiro as relações sociais se constituem no quadro do conflito de classes, enquanto, para o segundo, elas decorrem do consenso social.
}

Práxis Educativa, Ponta Grossa, v. 12, n. 2, p. 617-637, maio/ago. 2017 Disponível em: <http://www.revistas2.uepg.br/index.php/praxiseducativa > 
primeiro plano o caráter ativo, reflexivo, da conduta humana e, junto a isso, as tradições interpretativas da Sociologia. Nesse deslocamento, Touraine destaca o surgimento de "novos movimentos sociais" em que "novos atores sociais" passam a se manifestar na luta por seus direitos e emancipação social.

Foi, portanto, no contexto de reviravolta teórica nas Ciências Sociais, no quadro da crise da concepção clássica de modernidade (e todo o debate que constituiu e se seguiu à chamada "virada pós-moderna") que emerge a Sociologia da Infância como um novo campo de estudos, que se diferencia de outras disciplinas que, até então, tinham a infância e a criança como objetos de estudo subsumidos nas instituições família e escola. ${ }^{6}$

A Sociologia da Infância rompe, assim, com as abordagens clássicas da socialização que veem as crianças como seres passivos no processo educativo, o que fez com que o estatuto de ator social lhes tenha sido historicamente negado. Pode-se dizer que, nessa disciplina, o "paradigma da criança-ator" opõe-se, desse modo, ao "paradigma da produção do adulto" (BERNARD-BECHARIES, 1994). A passagem da compreensão da criança como objeto ou produto da ação adulta para a de um também agente de sua própria socialização é a grande mudança que se estabelece, e essa competência interacional que, mesmo as crianças muito pequenas possuem, constitui o que Bühler-Niederberger (2010, p. 159) chama de "paradoxo da socialização", já que se trata de um processo que só se concretiza se "todos os participantes são atores sociais capazes".

Autores da Sociologia da Infância têm argumentado que as dificuldades e as resistências que o meio científico apresenta ao reconhecimento da infância e das crianças como categorias conceitualmente autônomas e das crianças como atores sociais podem ser equiparadas às que as mulheres enfrentaram na conquista relativamente recente de seus direitos sociais e políticos, assim como o conceito de gênero para se estabelecer como categoria de análise social (ALANEN, 1990; PINTO, 1997). Não é de estranhar, portanto, que, como afirma Delalande (2014, p. 2), a "agência da criança" - como outras teorias sobre a infância que foram "emprestadas" dos estudos feministas - seja uma reação à situação histórica que considerou as crianças e as mulheres como atores fracos ou dominados. Assim, também Bühler-Niederberger (2010) assinala que o fato de, historicamente, as crianças serem vistas como estando "fora da sociedade" (isto é, apartadas da vida social e política) explica o fato de elas sempre terem estado também fora da Sociologia (com exceção dos estudos sociológicos de Durkheim, Parsons e Mannheim sobre socialização, que, justamente, buscavam compreender como as crianças e os jovens se "tornavam" atores sociais aptos à vida adulta).

\section{O (atual) debate sobre a criança-ator: ontogenia, ideal social ou conceito científico?}

Nesta parte do artigo, discutirei textos de autores que problematizam o princípio da "criança ator social" ou da "agência" da criança tal como proposto pela Sociologia da Infância, incluindo, nessa discussão, a maneira como autores de estudos etnográficos sobre crianças "de rua”, no Brasil e em outras partes do mundo, compreendem essa questão. É importante, de início, acrescentar que, além do problema histórico da não atribuição de agência social às crianças (anteriormente explanado), o que torna essa questão também muito complexa é o fato de que, além de não haver unanimidade sobre o conceito, também não há entendimento sobre onde (geográfica e/ou socialmente) ele pode ser utilizado e, ainda, sobre sua possível ou suposta "politização".

\footnotetext{
" Para Ferreira (2002), mais do que um “regresso do ator” é a “descoberta do ator-criança” que está em causa na SI.
} 
Lancy (2012) faz uma forte crítica ao conceito de "agência das crianças" nas pesquisas da área dos estudos sociais da infância, argumentando que "[...] não há diferença fundamental entre os 'libertadores das crianças' que tentam manipular a ciência para fazer avançar sua causa e o Papa que faz o mesmo em nome de sua agenda" (LANCY, 2012, p. 3, grifo do autor, tradução nossa). Assim, o autor considera o conceito um "dogma" já "institucionalizado" na análise do financiamento de pesquisas e denuncia o "efeito pernicioso" (ainda "pouco registrado ou conhecido") que faz com que os métodos e as perspectivas do arsenal do antropólogo sejam em grande parte reduzidos a uma "defesa aplicada" da concessão de autoridade às crianças para determinar o curso das pesquisas. ${ }^{7}$ King (2007), em artigo anterior, já realizara crítica semelhante ao afirmar que o "rótulo" de "sociologia" podia estar sendo usado para dar respeitabilidade e apoio científico para campanhas pelos direitos de participação das crianças e contra a sua opressão por adultos. Da mesma forma, Bühler-Niederberger e Krieken (2008, p. 149) consideram, endossando a crítica de King (2007), que os conceitos chave que circulam na Sociologia da Infância "[...] flutuam entre o registro analítico e o normativo", devido ao compromisso de pesquisadores com o incremento dos direitos das crianças, sendo essa "advocacia" especialmente verdadeira "para o conceito de agência da criança" e que, como resultado, esse conceito "tende a ser naturalizado ao invés de analisado".

Entretanto, não fica muito claro qual seria a principal queixa de Lancy (2012): se é endereçada ao conceito de agência da criança em si, devido aos "problemas" que o autor enumera (de início, parece ser essa a queixa principal, mas, em partes do texto e, especialmente, nas conclusões, ele incentiva os antropólogos a comprovarem o conceito!), ou se a queixa se endereça à forma como o conceito tem sido utilizado nas pesquisas. Nesse último sentido, ele argumenta que muitos pesquisadores que declaram assumir, à partida do estudo, o princípio da agência das crianças não conseguem ou não se preocupam em, efetivamente, demonstrar (por meio dos dados de campo) onde e como a agência das crianças se manifesta no contexto social observado. Muitas vezes os dados das pesquisas podem mesmo contrariar o princípio assumido, mas isso seria, segundo esse crítico, deliberadamente ignorado pelos pesquisadores. Ou seja, é como se, afirma Lancy (2012), bastasse ostentar o princípio da agência da criança para desobrigar os pesquisadores do rigor metodológico na condução das pesquisas.

No entanto, se, nas conclusões, o texto de Lancy (2012) apela aos pesquisadores que usem suas "armas empíricas" para demonstrar a agência das crianças, ele também critica o conceito pelo fato de, na forma como atualmente é predominantemente trabalhado pelos pesquisadores, ser um conceito "[...] etnocêntrico, classista e hegemônico, personificando o domínio do modelo burguês da educação das crianças contemporâneas" (LANCY, 2012, p. 1, tradução nossa). O conceito estaria impondo e privilegiando, portanto, uma única etnoteoria da infância, em detrimento de modelos e práticas alternativas presentes em outras partes do mundo.

Assim, para esse autor, os pesquisadores que utilizam o conceito o fazem em dois sentidos preponderantes - um associado à "eficácia" e outro à "liberdade" - que são encontrados em proporção inversa caso se esteja a falar de crianças do "Norte" ou do "Sul" do mundo. No primeiro caso, as crianças são ouvidas e atendidas pelos adultos em suas necessidades e seus desejos, tendo posição social e poder elevados. Inversamente, nos países do Sul, as crianças têm muita liberdade ("autonomia física"), mas sua agência tem pouca eficácia, e delas se espera que sejam úteis ao seu grupo social que, por sua vez, lhes atribui responsabilidades, mas não direitos.

\footnotetext{
7 Embora não mencione especificamente, o autor parece dirigir essa crítica centralmente às metodologias participativas com crianças no sentido que, por exemplo, Alderson (2005) defende.
}

Práxis Educativa, Ponta Grossa, v. 12, n. 2, p. 617-637, maio/ago. 2017 Disponível em: <http://www.revistas2.uepg.br/index.php/praxiseducativa > 
A partir disso, na tentativa de demonstrar o caráter etnocêntrico do conceito, o autor cita pesquisas etnográficas que destacam características tradicionais de obediência e submissão atribuídas às crianças (filhos) em sociedades não ocidentais, em contraste com a maneira emancipatória como pais de classe média alta das sociedades "do Norte" educam seus filhos.

Da mesma maneira, Bühler-Niederberger e Krieken (2008) argumentam que o conceito de agência das crianças não estaria levando em conta as diferenças e as distinções de classe, sendo essas diferenças decisivas para a emergência histórica da "infância moderna", permanecendo importantes para o bem-estar e as oportunidades de vida das crianças em todo o mundo. Assim, para esses autores, a noção de agência das crianças não seria adequada para crianças de sociedades não individualizadas (tradicionais) que têm acesso restrito às oportunidades de individualização e, mesmo quando aplicadas às "infâncias europeias", não se pode considerar que crianças ajam "para além do status e da classe", como agentes puramente individualizados, pois, na verdade, atuam sempre no quadro das estruturas sociais, econômicas e políticas que, muitas vezes, limitam o âmbito da possível ação.

Delalande (2014) inicia sua réplica ("reação") ao texto de Lancy (2012), publicado no mesmo periódico científico (AnthropoChildren), perguntando: Como, afinal de contas, definir o conceito de criança ator? Ela responde que, longe de ser algo adquirido, definir esse conceito é a tarefa de todo pesquisador que participa de uma reflexão coletiva. A autora argumenta ainda que, todo pesquisador - como cidadão - tem, naturalmente, opiniões, posições políticas e compromissos pessoais. Assim, se é suposto que o especialista em questões de infância geralmente "defenda" a infância e valorize as competências sociais e culturais das crianças, a busca por objetividade, no entanto, deve levá-lo a assumir uma postura distanciada de opiniões pessoais. ${ }^{8}$ Ou seja, trata-se de perceber se os pesquisadores descrevem, afinal, uma realidade que encontram na vida social ou aquela que desejariam que existisse? A autora, dessa forma, define o que entende pelo conceito de criança ator:

\begin{abstract}
Uma criança é um ator quando um adulto (cidadão e/ou pesquisador) reconhece a sua capacidade de agir e permite que exerça sua ação sobre o ambiente. É um indivíduo capaz de contribuir com a sua parte no jogo social, capaz de iniciativas e de pensamentos que contribuem na construção de nossa sociedade e que são consideradas pelos adultos assim como as iniciativas adultas. Em suas interações com os adultos, ela reage ao que lhe é proposto e/ou imposto (Sirota, 2005); em suas interações com seus pares ela ajuda na construção das "culturas infantis". (DELALANDE, 2014, p. 2, grifo da autora, tradução nossa).
\end{abstract}

Para essa autora, esses dois conceitos ("ator social" e "culturas infantis") retiram as crianças de uma representação social em termos de "seres em devir", reconhecendo sua capacidade de agir no mundo. Assim, a noção de ator (na Sociologia) ou a de sujeito (na Psicanálise) está associada nas nossas sociedades ocidentais à ideia do indivíduo que deve exercer sua autonomia para ser valorizado. No entanto, ressalta a autora, as crianças mantêm a capacidade de agir mesmo que isso não seja aceito ou reconhecido pelos adultos. Nesse caso é que ela as define como "atores nas sombras", porque não são vistas como parceiras dos adultos.

Aqui, por conseguinte, a autora parece de acordo com a definição que assumi para o conceito de criança ator na introdução deste artigo, pois as crianças são atores sociais independentemente do seu reconhecimento por parte dos adultos. E isso simplesmente porque

\footnotetext{
${ }^{8}$ Sendo, no entanto, “a criança sociológica moderna" um "terreno maduro para agendas alternativas", Jenks (2005, p. 60-63) defende que (para uma estratégia efetivamente fenomenológica da "colocação entre parênteses" da infância e da criança) “[...] não é necessário gostar de crianças, ter crianças, viver com crianças ou perspectivar as crianças como significativamente mais ou menos importantes do que qualquer outro grupo da sociedade, para realizar uma investigação interessante sobre a infância”.
}

Práxis Educativa, Ponta Grossa, v. 12, n. 2, p. 617-637, maio/ago. 2017 Disponível em: <http://www.revistas2.uepg.br/index.php/praxiseducativa $>$ 
são seres sociais, porque se comunicam com outros seres de sua própria cultura e, nessa comunicação, atuam na reprodução e também na produção de sentidos compartilhados (e aqui não me refiro apenas à comunicação das crianças no interior de suas "culturas infantis"). Ou seja, queiram os adultos ou não, reconheçam ou não a ação social das crianças, essa ação existe mesmo quando ela não é socialmente reconhecida ou valorizada ou, como no caso das crianças "de rua", é vista como desviante, criminosa ou essencialmente má (antissocial), como será visto adiante neste texto.'

Reportando-se à obra de Luís Dumont e também à de Norbert Elias sobre o individualismo moderno, Delalande (2014) destaca que a criança atual está plenamente inscrita em um modelo de sociedade democrática na qual o valor maior é o indivíduo que tem a obrigação de se afirmar como tal e de ser livre. Nesse sentido, pode-se retomar aqui a ideia de que a criança como ser individualizado, diferente do adulto, é produto do duplo processo histórico - de civilização e de individualização - que deu origem à era moderna. Esse processo que libertou e atribuiu direitos de cidadania inicialmente apenas aos homens, depois às mulheres, atingiu, em finais do século XX (com a Convenção sobre os Direitos da Criança - CDC), também as crianças (MARCHI, 2007).

Essa questão da individualização da criança, e que está expressa de forma cabal na CDC, é um ponto central no debate, pois, como visto acima, Bühler-Niederberger e Krieken (2008) consideram que o processo de individualização está presente apenas em determinadas sociedades (centralmente as europeias) e que, em outras, as crianças têm acesso restrito às oportunidades de individualização. ${ }^{10}$ Também Lancy (2012) argumenta que o modelo de criança "indivíduo" e, portanto, com direito a "direitos" (embora seja o modelo hegemônico), é apenas um entre muitos existentes no mundo. ${ }^{11}$

Voltando à réplica de Delalande (2014), ela afirma que há muitas maneiras de uma criança ser ator social e não apenas duas centrais, como supõe Lancy (2012). Ou seja, há tantas quantas são as maneiras que as diversas sociedades compreendem o papel e o lugar das crianças nas respectivas culturas. Assim, essa autora chama a atenção para uma contradição no argumento de Lancy (2012), pois, nos "registros etnográficos" que ele seleciona para demonstrar a falta de agência das crianças nas sociedades tradicionais (ou o "etnocentrismo" do conceito), o que surge

\footnotetext{
9 Aqui, pode-se fazer um paralelo à ação política das mulheres que, no final do século XIX e início do XX, lutavam pelo direito ao voto. Os homens a quem as sufragistas dirigiam seus apelos (políticos, patrões, maridos) ignoravam ostensivamente sua reivindicação e/ou as puniam com violência, embora elas trabalhassem arduamente em suas casas e fábricas, ao lado dos homens. Ou seja, a ação social das mulheres pelo direito ao voto era vista como desviante do modelo instituído de mulher e considerada criminosa porque ia contra a ordem social da época. Dessa forma, eram presas, torturadas, abandonadas pelos maridos, obrigadas a viver na clandestinidade, perdiam o emprego e a guarda dos filhos e eram até mesmo mortas em consequência da sua luta. Contudo, apesar de os homens não reconhecerem positivamente a ação das sufragistas, de não lhes darem "permissão" para atuar daquela forma, o movimento ativista cresceu e, graças a ele, atualmente, na maioria dos países do mundo, as mulheres têm direitos políticos iguais aos dos homens.

10 Para uma análise da CDC como documento que encarna um "avanço civilizacional” para a infância - apesar de suas fragilidades, eurocentrismo, incompletude e contradições entre o que prescreve e a realidade social -, ver Sarmento (2013, p. 37-42).

${ }^{11}$ Arce (2015) argumenta que a Convenção é guiada, em seus pressupostos, pela ideologia desenvolvimentista (sobre "a" criança e sobre a "ordem" mundial). Esse autor desenvolve uma tese emancipadora dos direitos da criança (que leve em conta o seu direito ao trabalho) e, por isso, se empenha em demonstrar o caráter etnocêntrico e adultocêntrico da CDC. Assim, critica o mito das teorias desenvolvimentistas e as consequentes características (passividade, inocência, fragilidade, dependência) atribuídas às crianças e que estariam presentes no texto/discurso da Convenção. O interessante é que esse autor cita, no entanto, uma obra de Lancy (2008) como uma fonte de dados etnográficos sobre a agência das crianças "desde mais tenra idade" em sociedades tradicionais (LANCY, 2008, p. 19 apud ARCE, 2015, p. 159).
}

Práxis Educativa, Ponta Grossa, v. 12, n. 2, p. 617-637, maio/ago. 2017 Disponível em: <http://www.revistas2.uepg.br/index.php/praxiseducativa> 
é, na verdade, as maneiras como as crianças contribuem, de forma ativa, com a (re)produção de suas culturas locais e, com isso, adquirem prestígio e reconhecimento por parte de suas famílias e comunidades em função dos valores que essas defendem. Ou seja, pode-se ver ali, ao contrário do que argumenta Lancy (2012), como as crianças exercem sua agência segundo normas e valores sociais e culturais do grupo a que pertencem, com práticas que unificam os seus membros.

Corroborando a leitura de Delalande (2014), podemos também utilizar (além dos exemplos que a autora cita), a revisão que Arce (2015) faz sobre a agência das crianças nas sociedades tradicionais e que desafia a visão ocidental, hegemônica, sobre as crianças como, essencialmente, dependentes dos adultos, devido, em grande parte, como já visto, à ideologia disseminada pelas "teorias do desenvolvimento" infantil e pelo conceito de "socialização". Arce (2015) propõe, em contrapartida, as crianças como ativas e colaboradoras, que agem em parceria com os adultos que as rodeiam. Nesse sentido, sugere que adultos e crianças têm, na verdade, uma relação de interdependência. Esse autor, no entanto, não restringe o conceito de agência infantil às crianças trabalhadoras das sociedades tradicionais e o estende também às crianças ocidentais em diversas atividades (realizadas individualmente ou no grupo de pares) no espaço da casa, da escola ou das ruas.

O que parece ficar claro é que, em sua crítica, Lancy (2012) assim como BühlerNiederberger (2010) consideram que o conceito de agência infantil só faz sentido quando atribuído à criança que tem à sua disposição os meios simbólicos e materiais para exercer sua vontade (e seu poder de agir); ou seja, às crianças das famílias de classes médias e superiores. Nesse sentido, é que Lancy (2012) define o conceito de agência infantil como etnocêntrico (ocidental), classista (presente somente nas classes abastadas) e não científico. ${ }^{12}$

Arce (2015), paradoxalmente, faz essa mesma crítica em relação ao conceito de "desenvolvimento infantil", classificando-o de "normativo", "natural" e "hegemônico". Nesse sentido, o autor critica o conceito (que nega, por princípio, a agência infantil) por suas características de "necessidade" (universalidade), "endogenia" e "teleologia".

Dispondo à mesa os argumentos dos diversos textos - como se dispõe uma mão de cartas -, o que parece ficar evidente na discussão é aquilo que Jenks (2002, p. 214) já assinalou: o fato de que a construção social da criança tem (como outras construções) intenções socialmente localizadas e, por isso, somos “[...] confrontados com diferentes crianças 'teóricas' que servem os diferentes modelos teóricos de vida social do qual emergem” (JENKS, 2002, p. 214, grifo do autor). Nesse sentido, é que, assim como cada época histórica, com sua ordem social, tem uma determinada visão hegemônica de infância, criança e seu modelo de educação - visão que é essencialmente política por ser ligada à emergência e à manutenção dessa ordem -, também na ciência trava-se uma disputa em torno do estabelecimento do conhecimento verdadeiro sobre a infância, as crianças e sua educação. Desde o início da modernidade, a ciência tem papel ativo na construção e na desconstrução das imagens sociais da infância e, nesse sentido, sua atuação

\footnotetext{
${ }^{12}$ Lancy (2012) critica também a ideia da criança como "produtora" de cultura e, mesmo que não cite o conceito de "culturas infantis", utilizado nos estudos sociais da infância, é certamente a este que se refere. No entanto, é tão breve e tão notadamente "funcionalista" sua crítica que é difícil dela tratar nos limites deste texto, bastando assinalar que o autor ignora trabalhos em sua própria área de conhecimento, como o de Hardman (2001), por exemplo, que já nos anos de 1970 defendia a criação de uma "antropologia da criança" (o fato de as crianças poderem ser "[...] estudadas por direito próprio e não apenas como receptáculos da cultura adulta”) (HARDMAN, 2001, p. 5). Essa antropóloga fez tal proposição baseada em estudos etnográficos clássicos como os estudos do casal Oppie (nos anos de 1960) e o de Margareth Mead (nos anos de 1930). Pode-se também destacar a exortação inicial à criação de uma "sociologia da infância" feita nos anos de 1930 por Marcel Mauss e, no Brasil, o trabalho pioneiro, nos anos de1940, dos sociólogos e antropólogos "folcloristas" Roger Bastide e Florestan Fernandes sobre as "trocinhas" (grupos de crianças que se formavam espontaneamente para brincar) nas ruas da cidade de São Paulo.
}

Práxis Educativa, Ponta Grossa, v. 12, n. 2, p. 617-637, maio/ago. 2017 Disponível em: <http://www.revistas2.uepg.br/index.php/praxiseducativa > 
sempre foi também politicamente localizada porque é dela - ciência - que emanam as ideias que hoje circulam sobre a infância e as crianças no meio social.

Da mesma maneira, observando esse leque aberto de argumentos e contra-argumentos sobre o princípio da criança ator e, em última instância, sobre a "cientificidade" da Sociologia da Infância, surge aquilo que Sarmento (2008) reiteradamente destaca como síntese das "correntes e controvérsias" teóricas e metodológicas que compõem e atravessam esse campo.

Sarmento (2013) responde especificamente à crítica feita à "politização" da área (problema, no mais, já anunciado por Règine Sirota (2001) em uma das primeiras publicações da Sociologia da Infância no Brasil) $)^{13}$, argumentando que ele pode ser localizado no "conflito epistemológico" entre a concepção weberiana de neutralidade axiológica (que preconiza a suspensão dos juízos de valor e das opções políticas e sociais no exercício da produção científica) e uma concepção epistêmica que sustenta não ser a ciência destituída de valores e opções políticas; sendo parte intrínseca do mètier do pesquisador. No entanto, fazer uso da estratégia de reflexividade é o cuidado permanente com as condições e os limites da validade de técnicas e de conceitos utilizados na realização de toda investigação. ${ }^{14}$ Isso é o que Delalande (2014) também assinalou acima sobre o "interesse heurístico" do conceito de criança ator que deve ser avaliado por cada pesquisador. Note-se que esses dois defensores do conceito estão, de certa forma, apelando para aquilo que Pierre Bourdieu chamou de "vigilância epistemológica" na pesquisa, pois, se o sociólogo consegue produzir alguma verdade, não é apesar de seu interesse, mas por causa dele, o que contraria o discurso da neutralidade científica (SILVA, 2012) ${ }^{15}$

Samuelson et al. (2015), levando em consideração as críticas de Lancy (2012) e, também, as de Prout (2005), sobre o fato de a "agência da criança" ser considerada geralmente pelos pesquisadores como um dado ontológico (natural, não problematizado) e sobre a tendência nos estudos sociais da infância a sobrevalorizar a competência das crianças, discutem o fato de, na verdade, essa categoria ser co-construída no campo da pesquisa por diversos fatores, em particular pelos métodos utilizados nas investigações. Ao discutir o processo de produção de uma investigação etnográfica, os autores chegam à conclusão que a competência demonstrada por uma criança de 5 anos em uma visita a um centro cultural foi resultante de uma interação (interdependência) da criança com artefatos materiais (ali especialmente disponibilizados para esse fim) e outras pessoas, centralmente, a figura do pesquisador. Assim, eles argumentam que a agência da criança precisa ser colocada em relação a uma rede de interações que, geralmente, não são elucidadas nas pesquisas.

Essas considerações sobre o método referem-se àquilo que muitos etnógrafos já se referiram e que é a necessidade de esclarecer o processo da produção de dados, de modo que as condições em que a pesquisa foi realizada se constituam em variáveis importantes para os resultados da investigação (CICOUREL, 1980). Esse cuidado na hora da exposição e análise dos

\footnotetext{
${ }^{13}$ Controvérsia que é, segundo Sarmento (2013), de certa forma, transversal às correntes sociológicas (estruturalista, interpretativa e crítica) que compõem o campo.

${ }^{14}$ Sarmento (2013, p. 35-36) também destaca que a Sociologia da Infância nasce do "[...] longo trabalho de resgate, idêntico a outros realizados com categorias subalternas (as mulheres, os negros, os povos pós-coloniais, os homossexuais) que a ciência normal classicamente menosprezou e ignorou" e que: "Tal como os estudos feministas ou os estudos pós-coloniais não são compreensíveis fora da luta das mulheres contra a dominação patriarcal e dos povos subalternos contra a dominação cultural pelos países centrais", também os estudos sociais da infância "[...] só são inteligíveis pelo efeito de desocultação dos processos de dominação geracional e pela promoção de um conhecimento que recusa o adultocentrismo para aceder à alteridade infantil".

${ }^{15}$ Em referência a Durkheim, no seu esforço de tornar a sociologia uma ciência universitária, Bourdieu afirma que essa disciplina nasce mascarada com a aparência de pura e neutra (sem história), tendo sido levada a renegar sua condição política para ser aceita no campo científico (SILVA, 2012).
}

Práxis Educativa, Ponta Grossa, v. 12, n. 2, p. 617-637, maio/ago. 2017 Disponível em: <http://www.revistas2.uepg.br/index.php/praxiseducativa > 
resultados da pesquisa refere-se a toda e qualquer investigação, independentemente da faixa de idade dos participantes. Entretanto, no caso das pesquisas com/sobre crianças, devem especialmente ser levadas em conta de modo a matizar ou qualificar o pressuposto da criança ator assumido à partida. Assim, como argumentam Samuelson et al. (2015), a produção da criança competente/ativa no processo da pesquisa não deve ser vista como uma questão de "métodos deficientes" ou algo que deva ser corrigido com treinamento ou novos métodos, mas o fato de que nenhum estudo pode assegurar uma representação da ação das crianças sem mediação. ${ }^{16}$

Sem poder aprofundar aqui a discussão sobre a clássica antinomia entre ação e estrutura, é incontornável, no entanto, que, ao se falar da criança como ator social, essa complexa questão venha à tona. Nesse sentido, Elias (1994, p. 23) fornece importante contribuição ao definir a sociedade como uma "[...] rede de funções que as pessoas desempenham umas em relação às outras" e que, nessa "rede", a unidade de observação são as relações entre. ${ }^{17}$ Assim, no caso dos estudos da criança, não devemos, por força do movimento de reação contrário ao entendimento das crianças como seres determinados unilateralmente pelas estruturas ou instituições sociais, buscar compreender o "em si" da criança; a criança "antes" de qualquer relação. Isto é, não se pode pensá-las como "[...] postes sólidos entre os quais, posteriormente, se penduram os fios dos relacionamentos" (ELIAS, 1994, p. 25) - a "ligação posterior" que ela teria com os pais, demais parentes, vizinhos, com os pares, professores, etc.

É esse o impasse metodológico a que leva essa complexa discussão: o fato de que, ao mesmo tempo em que se faz necessário reconhecer as crianças como atores sociais, é preciso opor - simultaneamente - reservas a esse princípio, no que diz respeito a uma excessiva ênfase que, se particularmente necessária em um primeiro momento (o da constituição do campo da SI nos anos 80 e 90), tornou-se teoricamente inadequada por sua mera repetição no atual estágio da disciplina, tal como já considerou pioneiramente Prout (2005) em um processo de autocrítica do campo. ${ }^{18}$ De acordo com esse autor, já chegou ao fim o momento no qual os estudos sociais da infância deveriam realçar suas diferenças (em relação aos estudos tradicionais sobre as crianças). Ele critica a tendência de repetirem-se as ideias básicas da SI (tais como a da criança-ator), como se estas ainda fossem novidades que não tivessem sido já unanimemente aceitas (PROUT, 2005). Nesse mesmo sentido, em artigo sobre os "primeiros passos" da SI à sua "crise de crescimento", Mollo-Bouvier (2006, p. 28) afirma esperar que, ao falar da "ação das crianças" não somente sobre suas próprias vidas, mas também sobre a organização e a transformação da sociedade, não "[...] esteja fazendo mais do que redizer evidências" ou, como afirma Sirota (2005, p. 36), que não se esteja afirmando mais que uma "[...] banalidade por muito tempo negada ou ignorada".

Quando esses autores se referem à "banalidade" da agência das crianças ser devidamente reconhecida pela Sociologia, não estão reiterando o fato de que essa capacidade de ação dispensa análises, matizes ou interpretações; pelo contrário, sugerem que é a partir dessa constatação inicial

\footnotetext{
16 Quentel (2004), psicanalista, partilhando da crítica à psicologia desenvolvimentista na forma adultocêntrica com que foi concebida, faz também uma crítica à sociologia que nega explícita ou implicitamente a especificidade da criança diante do adulto; ou seja, que atribui à criança a mesma capacidade de tecer o laço social. $\mathrm{O}$ autor cita como ilustrativos dessa orientação os trabalhos de Règine Sirota e Patrick Rayou (representantes da Sociologia da Infância francesa). Para esse crítico, mal interpretadas, essas orientações levariam à "desresponsabilização" do adulto e da sociedade diante das crianças. Não sendo possível aprofundar a discussão, a menção feita é no intuito de delinear o quadro em que diversas posições teóricas (situadas em diferentes campos do conhecimento) se colocam.

17 Latour (1994) e Bauman (1999) são pensadores que também tratam a questão da inadequação das polarizações ou dicotomias no estudo da sociedade, e Prout (2005) trouxe essa discussão para dentro da Sociologia da Infância.

18 Esse autor assinala que um problema é o fato de que, nos estudos, a "ação das crianças" é frequentemente analisada de maneira breve, sem muitas explicações, pois é tida como característica humana essencial, ou seja, como ontológica.
}

Práxis Educativa, Ponta Grossa, v. 12, n. 2, p. 617-637, maio/ago. 2017 Disponível em: <http://www.revistas2.uepg.br/index.php/praxiseducativa> 
que se deve buscar as formas como essa ação (com mais ou menos autonomia) se evidencia ou se processa nos diversos contextos de vida das crianças. Assim, também Oswell (2013), em recente análise sobre essa questão, assinala que não se pode considerar o conceito de agência infantil como um "rótulo" ou algo que as crianças, individualmente, "possuam", como um "poder" a "He-Man" ("Eu tenho a força!"), mas que essa ação é sempre coletivamente engendrada (tem origem no "nós" e não no "eu"), estando apoiada em uma rede de disposições humanas e não humanas.

\section{As crianças "de rua" como atores sociais - a dualidade da estrutura}

Delalande (2014) argumenta que, embora os conceitos de "criança ator" e o "de culturas infantis" permitam trabalhar a eterna questão da alteridade da criança em relação ao adulto, o pesquisador deve colocar a si mesmo o interesse heurístico desses conceitos diante do que encontra no campo da pesquisa de modo a não os assumir como fato "adquirido". Se essas questões de método parecem óbvias é, no entanto, justamente sobre sua possível má condução que Lancy (2012) realiza críticas aos estudos sociais da infância, como visto anteriormente.

Sem poder responder pelos outros pesquisadores, a seguir, apresento a maneira como cheguei à categoria criança ator em minha investigação etnográfica sobre crianças "de rua", no Brasil (MARCHI, 1994), e em uma análise de etnografias sobre essas crianças em outros países (MARCHI, 2007).

Foi centralmente a percepção - durante a realização de uma etnografia sobre o cotidiano de crianças "de rua" em uma capital brasileira - de que as crianças observadas se contrapunham às ideias correntes de "infância" e de "criança" que me fez procurar ferramentas teóricas para a interpretação de suas maneiras de ser e estar no mundo. Ou seja, eu não parti dos estudos sociais da infância para construir e interpretar meu objeto de estudo (como sugere Lancy (2012) em sua crítica generalizante sobre os demais estudos); ao contrário, foram os meus dados de campo que me fizeram chegar à Sociologia da Infância e ao princípio da criança como ator social (MARCHI, 1994).

Realizei minha etnografia em 1991 quando recém tinha vindo a público a Convenção de 1989 que instituía a criança como um "sujeito de direitos" (portadora de todos os direitos humanos), enquanto no Brasil era promulgado o Estatuto da Criança e do Adolescente (ECA Lei N. 8.069, de 13 de julho de 1990). Na academia, a obra seminal de Ariès já vinha, no entanto, desde os anos de 1970, realizando o trabalho de desmontagem do que era considerado inquestionável sobre a infância, as crianças e o seu lugar na sociedade e instalando, contra pressupostos essencialistas e naturalizados, a ideia da "construção social" desses conceitos.

Foi o campo da pesquisa, portanto (isto é, o contato com as crianças "de rua"), que me permitiu ver (toda) a infância como uma construção política, ou seja, uma forma de controle e subordinação (das crianças) ao modelo da ordem. Um campo de disputa política tanto no que diz respeito ao seu "caráter de classe" (de modelo social hegemonicamente instituído) quanto no que se refere às relações de poder entre gerações. No entanto, as crianças na rua também me permitiram ver que, longe de serem ou se comportarem como simplesmente vítimas de uma situação de dominação adulta e de exclusão e violência social, também atuavam na negociação de suas condições de vida e de identidade. Assim, construí uma etnografia sobre o seu modo de vida baseada na compreensão adquirida no contato com elas: aquelas crianças agiam no mundo que as cercava com mais ou menos autonomia (tal qual nós mesmos, "adultos integrados", o fazemos no nosso cotidiano "normalizado"). Na época, por falta ainda do conceito de "ator social" (não 
comumente atribuído às crianças), fiz uso da expressão "crianças espertas" encontrada em Foucault (1988).

Anos mais tarde, em meu estudo de tese, esse meu estudo etnográfico e etnografias realizadas sobre crianças "de rua" em diversas outras partes do mundo levaram-me a considerar (uma vez desconstruída a ideia naturalizada da criança como ser dependente e submisso) que a criança "de rua" pode ser vista como o paradigma da criança ator, pois é a que mais visivelmente escapa à ação dos adultos sobre si (MARCHI, 2007). Sendo próprio das crianças ter sua socialização e educação a cargo de instituições, assim como comportamento heterônomo e "infantil", as crianças "de rua" estão na mão oposta dessas normas, pois escapam às malhas disciplinadoras da díade família-escola. A sua situação é, assim, a de uma "dupla alteridade": o fato ontológico de serem crianças e o fato social e político de não estarem regularmente submetidas às instituições socializadoras que têm por função habilitar o convívio social (MARCHI, 2007).

Afastada das instituições socializadoras, a criança "de rua" é normalmente vista, pela sociedade, ou como "vítima", porque é ameaçada em sua cidadania (no fenômeno da "exclusão social"), ou ameaçando a ordem social. Nessa última representação, o papel de ator social somente lhe é concedido na forma "negativa"; isto é, como "delinquente": a criança que pratica a ação socialmente "má" (infracional). Ao provocarem um "curto-circuito" nos processos de socialização previstos para todas as crianças na sociedade, as crianças "de rua" desenvolvem uma "economia de predação" como forma de "realização de si" que pode conduzir à morte (é quando é também vista como ameaça a si mesma), mas também ao tornar-se adulto (LATOUR, 1999). $\mathrm{Ou}$ seja, esse tipo de socialização pode ser compreendido como forma alternativa (mas fortemente proscrita) de desenvolvimento individual (ou de individualização).

No final da década de 1980, outra polarização instalou-se; dessa vez, no interior da produção acadêmica sobre as crianças. Assim, "imagens conflitantes" das crianças "de rua" decorriam do resultado das próprias pesquisas (NEIVA-SILVA; KOLLER, 2002): ao lado da ideia de "vítima" (que se deve resgatar da exploração e exclusão social) surge a de "ator social" (que busca um caminho alternativo e viável para a idade adulta). ${ }^{19}$ Contudo, a imagem da criança "de rua" como vítima foi predominante na produção acadêmica brasileira até, pelo menos, a virada deste século, sendo o paradigma da criança-ator pouco adotado nas análises até essa data.

Embora opostas, as imagens de "vítima" e de "delinquente" são igualmente redutoras e limitadoras da ação social dessas crianças. Como "vítimas", tornam-se receptoras passivas de todo tipo de ajuda que pode aliviar suas carências, mas inspiram reflexões que tendem a privá-las dos seus direitos de participação e expressão na sociedade. Inversamente, à criança "delinquente" são atribuídas capacidades e responsabilidades "adultas", porque simbolizam uma ameaça à sociedade que deve dela se proteger com estratégias de penalização e repressão (ZAMUDIO; TESSIER; LECOMTE, 2001). Em ambos os casos, a criança torna-se objeto de intervenções decididas somente por opiniões, pensamentos, julgamentos, ações e sentimentos de outras pessoas (adultos) (STOECKLIN, 2000; LUCCHINI, 1993; ZAMUDIO; TESSIER; LECOMTE, 2001).

As conclusões a que cheguei com meus dados de campo foram, ao longo do tempo, sendo corroboradas por outros pesquisadores que, com maior, menor, ou nenhuma vinculação aos novos estudos sociais da infância, chegaram às mesmas conclusões em suas pesquisas sobre

\footnotetext{
${ }^{19}$ Rosemberg e Freitas (2006) também notam que, desde fins dos anos de 1980, estudos sobre "trabalho infantil” não mais reduzem o fenômeno à "exploração capitalista da força de trabalho" e, mesmo não acatando abertamente os princípios dos estudos sociais da infância, nesses trabalhos a criança é considerada um ator social.
}

Práxis Educativa, Ponta Grossa, v. 12, n. 2, p. 617-637, maio/ago. 2017 Disponível em: <http://www.revistas2.uepg.br/index.php/praxiseducativa> 
ou com crianças "de rua" em outras cidades do Brasil, da América Latina e em outras partes do mundo (China, República do Congo, Costa do Marfim, Canadá). Outros pesquisadores também apontaram, então, para a capacidade das crianças de utilizar, a seu favor, nas relações do cotidiano, imagens e discursos (tanto os negativos quanto os gerados pela "compaixão") produzidos sobre si. Essa capacidade é denominada de "esperteza" (MARCHI, 1994), "viração"20 (VIANNA, 1999; GREGORI, 2000), "débrouillage" (PARAZELLI, 2002), "bricolagem" (MARCHI, 2007; OSWELL, 2013). É nesse sentido que se pode falar de uma construção de si e da busca de reconhecimento social, por parte dessas crianças, (mesmo que ele venha na forma negativa) que pressupõe e também acarreta relativa autonomia. ${ }^{21}$

A vitimização das crianças "de rua" chinesas (STOECKLIN, 2000) e africanas (LATOUR, 1999; D'HAEYER, 2004) são exemplos extremos em que o pesquisador poderia não ver mais que a força das estruturas sociais excludentes determinando e explicando suas vidas. Entretanto, mesmo nesses casos, as crianças desenvolvem (com mais ou menos domínio) formas de ação que impedem que as olhemos como nada mais que vítimas sem recursos a quem podemos classificar e falar em seu nome. ${ }^{22}$ Nesse sentido, "[...] é observando como cada criança 'organiza' com mais ou menos domínio sua relação com o mundo da rua que a gente a pode ver como um ator social e não unicamente como vítima ou delinqüente" (STOECKLIN, 2000, p. $45)^{23}$

$\mathrm{Na}$ etnografia que realizei, o esforço interpretativo deu-se no sentido de sugerir o que hoje se encontra expresso, então, de forma mais geral, na Sociologia da Infância: a criança não é somente produto das (macro) estruturas sociais, por mais opressivas e excludentes que sejam. Considerar a criança como ator não significa dizer que seja autônoma, ao contrário, significa ver como, em um dado contexto, ela pode adquirir mais ou menos autonomia. Assim, Stoecklin (2000) e Lucchini (1993) consideram que os motivos de maior ou menor autonomia na rua não se devem às características pessoais de determinadas crianças, mas à natureza das relações sociais presentes nesse espaço.

Importa, portanto, também conhecer a imagem que essas crianças fazem da rua, que depende das oportunidades materiais, sociais e identitárias que ali encontram e das representações e reações sociais às suas presenças "fora de lugar". O cotidiano na rua implica negociações e exige competências que influenciam a imagem e a autoestima da criança. Compreendemos, então, que a motivação a permanecer na rua (ou dela querer sair) depende, em grande parte, da visão que a criança tem de si mesma como agente mais ou menos competente nesse espaço (STOECKLIN, 2003).

A valorização e a incorporação na reflexão sociológica de uma orientação que considere as crianças como atores sociais (e cuja compreensão da própria situação deve ser levada em conta

\footnotetext{
20 "Viração" não significando somente estratégias que visam conseguir recursos materiais, como comumente é identificada essa prática, mas também como recurso simbólico de negociação de identidade (GREGORI, 2000).

21 O maior indício do grau de autonomia das crianças "de rua" está dado pela sua desinstitucionalização (longe da família e da escola), o fato de sua "circulação" acontecer à revelia ou apesar das decisões adultas sobre si. Para uma análise dos "olhares cruzados sobre a autonomia" dessas crianças, ver Stoecklin (2003, p. 279-306).

22 Isso porque os fatores estruturais que marginalizam as crianças e que são determinantes no fenômeno não permitem, no entanto, explicar suas trajetórias e comportamentos efetivos nas ruas (STOECKLIN, 2000; LUCCHINI, 1993).

23 Da mesma forma, Parazelli (2002, p. 11) considera que a heterogeneidade dos percursos dos jovens "de rua", assim como a dos jovens adultos itinerantes, deve tornar o pesquisador prudente no trabalho de interpretação do fenômeno, “[...] deixando um lugar importante à palavra dos jovens e, por consequência, à sua própria análise deles mesmos".
}

Práxis Educativa, Ponta Grossa, v. 12, n. 2, p. 617-637, maio/ago. 2017 Disponível em: <http://www.revistas2.uepg.br/index.php/praxiseducativa $>$ 
pelo analista) devem considerar os modos como os atores sociais se apoiam nas propriedades estruturais para a constituição das relações sociais. Isto é, devem levar em conta a dualidade entre a coerção estrutural e a conduta intencional que Giddens (1989) propõe no sentido de uma mudança da perspectiva institucional (em que as propriedades estruturais são vistas como cronicamente reproduzidas) para o estudo da ação intencional ou estratégica.

Ao denominar as crianças "de rua" como "crianças espertas" (MARCHI, 1994) ou como "bricoleurs" (MARCHI, 2007), levei em conta sua própria "visão de mundo" que, baseada nas suas condições objetivas de existência, recusava ativamente o papel de "vítimas", de "pobres coitados", de "abandonados". Faziam questão, complementar à recusa da apatia e passividade que lhes eram imputadas ou da imagem de delinquentes, de afirmarem-se "donos de si". Nesse sentido, meu estudo apontou, de forma inicial, para o que hoje é considerado sinal do "papel ativo" das crianças "de rua" detectado nos estudos sociais da infância no Brasil - a sua "circulação" entre vários espaços $(\mathrm{COHN}, 2005)^{24}$ - e sua ação como uma espécie de bricolage que lhes permite (sobre)viver com os poucos recursos materiais e simbólicos que têm à mão, como recentemente afirmado também por Oswell (2013).

A vida das crianças nas ruas deve, portanto, ser considerada como resultado de múltiplas influências de elementos objetivos e subjetivos que cada criança organiza - com mais ou menos domínio - de maneira ativa. São essas competências que é preciso reconhecer e conhecer se realmente queremos compreender sua situação. Quando se nega suas competências, a tendência é que a criança prefira permanecer na rua, no espaço onde ela pode exercer sua ação porque é, a partir dela, por mais desviante que nos pareça, e não a partir de um projeto de ressocialização (que lhe é imposto de fora), que ela constrói sua autoestima e percepção de si. Assim, sem obviamente negar a vitimização dessa criança, é preciso analisar não somente o que é feito a ela, mas também o que ela faz com o que fazem dela (SIROTA, 2001). Afinal, saber como as crianças lidam com aquilo que lhes é proporcionado pelos adultos sintetiza as "dificuldades de toda educação" (BERNARD-BECHARIES, 1994).

A discussão da criança "de rua" como ator social não é um movimento que, por reação contrária à unívoca vitimização da criança (que se mostra em xeque no campo da pesquisa), tenderia a estabelecer o oposto absoluto - a criança "ator competente" com pleno domínio das adversas condições de vida que enfrenta no seu cotidiano de escassez. Concordo com Buckingham (2002) que ambas as visões são igualmente "construções da infância" e detêm um apelo emocional genuíno, embora de tipo diferente. E que ambas tendem a simplificar em excesso a complexidade e a diversidade do comportamento das crianças diante da vida. Nesse sentido, a compreensão da criança "de rua" (e também das demais crianças) não deve ser essencialista (ativa ou passiva; competente ou incompetente). $\mathrm{O}$ fenômeno tem antes que ser visto como associado ou resultante do processo moderno de individualização que, mesmo na consignação de direitos individuais e, sobretudo, na prescrição normativa de cada um para conduzir a "própria vida" a partir de escolhas e opções "individuais”, não é, como assinalam Beck e Beck-Gernsheim (2003), uma questão de simples "subjetividade" ou de ação que se desenvolva em espaço "virtualmente vazio", pois não é independente das posições que os indivíduos ocupam na estrutura social e, por isso, se processa de forma diferenciada junto aos atores concretos (isso é, de forma geral, também o que afirmam Prout (2005) e Bühler-Niederberger e Krieken (2008).

O traço a ser destacado nas biografias das crianças "de rua" é o fato de que o princípio geral das sociedades modernas - a administração da própria vida pelos indivíduos; a conversão da

${ }^{24}$ Cohn (2005, p. 31-33) atribui, no entanto, o conceito de "circulação" a uma etnografia (GREGORI, 2000), realizada meia década após meu estudo.

Práxis Educativa, Ponta Grossa, v. 12, n. 2, p. 617-637, maio/ago. 2017 Disponível em: <http://www.revistas2.uepg.br/index.php/praxiseducativa> 
biografia normal em "biografia reflexiva" ou a "biografia faça-o você mesmo" -, assume, junto às crianças "de rua" um caráter paroxístico porque a sua individualização é marginal ao processo de individualização das outras crianças, aquelas submetidas à norma das instâncias socializadoras. ${ }^{25}$ Nesse sentido, as crianças "de rua" são as que levam o princípio de individualização aos seus limites - por não terem a supervisão adulta - e, dessa forma, antecipam e anunciam uma "crise da educação" que hoje vemos traduzida na chamada "crise social da infância" (SARMENTO; MARCHI, 2008).

Desse modo, e aprofundando um pouco a visão inicialmente esboçada por ocasião de minha etnografia sobre crianças "de rua", considerei, em Marchi (2007), que o poder e a dominação não estão somente no nível das estruturas econômicas e sociais, ou associados apenas a este ou àquele espaço (à casa ou à rua), mas também relacionado à desigualdade (assimetria) de poder entre crianças e adultos, isto é, manifestos também nas relações intergeracionais, que são igualmente estruturais e estruturantes. Essa mudança de enfoque é uma forte contribuição que a Sociologia da Infância pode trazer aos estudos realizados no Brasil e em outras partes do mundo sobre o fenômeno das crianças "de rua". Stoecklin (2003) e Latour (1999), por exemplo, consideram que, quando crianças afirmam vivenciar uma sensação de liberdade nas ruas, elas estão referindo-se aos aspectos sociais e simbólicos deste espaço que correspondem à possibilidade de escaparem à ação e a demandas de "[...] adultos que tentam mantê-las em uma posição submissa e reprodutora” (STOECKLIN, 2003, p. 110). Essas crianças, enquanto não submissas ao grupo doméstico e como desterritorializações do universo disciplinado, preferem a diluição e a horizontalidade das relações de violência e de dominação que se estabelecem nas ruas, ao clima denso da autoridade vertical que se assenta dentro de casa, das escolas, das instituições de atendimento (MARCHI, 1994).

\section{Considerações finais}

No que segue, à guisa de conclusão, retomo o que denominei de desafios teóricos e empíricos relativos à ideia da criança como ator social nas pesquisas. É importante destacar que as críticas sobre o princípio da criança ator não são recentes como pode fazer supor o texto de Lancy (2012), pois críticas ou relativizações a esse conceito surgiram já pouco tempo depois do surgimento da Sociologia da Infância, vindas tanto do exterior quanto do interior dessa disciplina. Ou seja, passado o tempo em que essa era uma "obviedade" a ser reconhecida de modo a lutar contra a invisibilidade epistemológica da infância/criança como objetos de estudo legítimos e autônomos, surgiram os primeiros alertas para o risco desse princípio sofrer distorções ou vulgarização em seu significado, tanto no nível do "senso comum douto" quanto no nível do cotidiano. Assim, se entender a criança como "ator social" não é tarefa simples nem realizável de uma só vez, a simples "substituição" de um paradigma por outro, sem que se considerem as consequências dessa conversão, pode gerar equívocos que, partindo do plano teórico, vão se refletir nos planos social e político.

A ideia de infância, assim como das emoções e dos valores que a acompanham, como sugerem os sociólogos da infância, não é algo dado nem inamovível, estando antes sujeita a um constante processo de definição, de uma batalha social e política (tanto na esfera pública quanto na privada) por seu significado e valor. Desse processo participam tanto os adultos (e as diversas estruturas e instituições sociais) quanto, em condições desiguais de voz e poder, as próprias

\footnotetext{
${ }^{25}$ Note-se que essa visão contraria à esboçada por Bühler-Niederberger (2010) e, especialmente Lancy (2012), que considera que ações das crianças que contrariam o seu bem-estar (como circular/viver nas ruas ou se prostituir como forma de sobrevivência), não pode ser considerada como "agência", porque não são ações que pressupõem "eficácia".
}

Práxis Educativa, Ponta Grossa, v. 12, n. 2, p. 617-637, maio/ago. 2017 Disponível em: <http://www.revistas2.uepg.br/index.php/praxiseducativa> 
crianças, como atualmente se reconhece. A nova compreensão da criança como ator apresenta, assim, à ciência, diversas formas e graus de dificuldade teórica, como apresentado neste artigo.

Deixar, como tem feito a Sociologia da Infância, de entender a criança como um ser passivo ou que não tem "nada" a dizer sobre o mundo em que vivemos é, obviamente, uma atitude positiva que abre a possibilidade de pensar o mundo com a sua participação e modo próprio de pensar e agir. O problema, no entanto, encontra-se no movimento de, novamente, tornar absoluto o que acabou de ser relativizado. Ou seja, a descoberta da criança como ator social e a divulgação/vulgarização desse novo paradigma nos diversos níveis acadêmicos, indo refletir-se nas práticas cotidianas, pode levar a equívocos como o de compreender a "agência" infantil um fator tout court de emancipação da criança, como indivíduo de pouca idade, da dependência do indivíduo adulto. Como pondera Buckingham (2002), a substituição, pela Sociologia da Infância, da ideia da criança "incompetente" (construída pela psicologia) pela ideia da criança "competente" que compreende o mundo em seus próprios termos e que é capaz de tomar decisões sobre sua própria vida pode, como consequência - nessa "reação em excesso" contra a histórica subestimação social das crianças -, atribuir-lhes um grau de conhecimento e autonomia que também não corresponde à realidade.

A dificuldade e a delicadeza dessa tarefa teórica residem na especificidade que constitui a criança, pois, se não se pode atribuir aos adultos total autonomia e independência em relação às estruturas sociais, não se pode fazê-lo, igualmente, em relação às crianças (isto seria considerá-las "super" atores!) considerando, ainda, o fato de que a vida e o comportamento das crianças são mais normativamente visados e prescritos pelas instituições. Assim, creio que a atual ênfase sobre a criança como "ator social" revela-se especialmente problemática no que ela pode acarretar um efeito contrário ao que pretendem os pesquisadores. Ou seja, ao se "emancipar" teoricamente as crianças, trazendo-as do fundo da cena teórica (ou da invisibilidade a que estavam relegadas), para o primeiro plano da análise, pode-se, em um movimento simultâneo e que envolve as questões da reflexividade do conhecimento no senso comum douto (na expressão de Bourdieu), falsificar a dimensão do fenômeno. O risco é o de que, uma vez caída no "senso comum" dos pesquisadores, a ideia da criança como ator social competente pode levar à falsa impressão de que o cotidiano social das crianças tenha, como que por um passe de mágica teórica, se transformado radicalmente.

Creio que é nisto que se deve insistir: o que se transformou foi o modo como a sociologia passou a entender a participação das crianças na construção do mundo em que vivem - tanto o "infantil" quanto o "adulto" (e que as antecede, envolve e ultrapassa) e não suas condições concretas de existência como indivíduos menores de idade a quem são negadas as competências "adultas". ${ }^{26}$

A propalada emancipação pode ou não estar presente na experiência concreta de crianças, mas, de toda forma, a relação entre o discurso científico e a realidade à que ele se refere precisa estar situada no quadro da reflexividade da vida social moderna, ou no que Giddens chama de "dupla hermenêutica" como um "modelo de reflexividade" nas Ciências Sociais: os saberes produzidos sobre as práticas sociais cotidianas e elas mesmas realimentam-se mútua e continuamente. É por isso que a "dupla hermenêutica" consta como um dos princípios na construção do novo paradigma nos estudos sobre a infância. Ou seja, teorizar sobre o fenômeno implica envolver-se no seu processo de desconstrução/reconstrução. Assim, os "riscos" ou as

\footnotetext{
${ }^{26}$ James e Prout (1990) assinalam que as crianças serem vistas como atores sociais não obscurece o fato de suas vidas serem determinadas em larga medida pelos adultos, além de serem o grupo social que em muito poucas situações consegue representar-se independentemente. Ainda, as políticas educacionais e os processos legais e administrativos têm profundos efeitos na vida das crianças enquanto estas têm pouca ou nenhuma influência sobre aqueles.
}

Práxis Educativa, Ponta Grossa, v. 12, n. 2, p. 617-637, maio/ago. 2017 Disponível em: <http://www.revistas2.uepg.br/index.php/praxiseducativa> 
"consequências" do que afirmarmos sobre a infância e as crianças recairão muito provavelmente sobre elas próprias e sobre as formas sociais de sua compreensão. Entendo que deva ser nesse sentido que os autores aqui mencionados situem suas críticas e alertas ao discurso especialista. ${ }^{27}$

\section{Referências}

ALANEN, L. Rethinking socialization, the family and childhood. In: ADLER, P. A.; ADLER, P; MANDELL, N. Sociological studies of child development. v. 3. Bingley: JAI Press Inc., 1990. p. 13-28.

ALDERSON, P. As crianças como pesquisadoras: os efeitos dos direitos de participação sobre a metodologia de pesquisa. Educação \& Sociedade, Campinas, v. 26, n. 91, p. 261-280, maio/ago. 2005. DOI: 10.1590/s0101-73302005000200007

ARCE, M. C. Hacia un discurso emancipador de los derechos de las niñas y los niños. Lima: IFEJANT, 2015.

BAUMAN, Z. Modernidade e ambivalência. Rio de Janeiro: Jorge Zahar, 1999.

BERNARD-BECHARIES, J.-F. Quels paradigmes pour une théorie de l'enfant acteur? Revue de l'Institute de Sociologie, Université Libre de Bruxeles, n. 1-2, p. 21-37, 1994.

BECK, U.; BECK-GERNSHEIM, E. La individualizacion: el individualismo institucionalizado y sus consecuencias sociales y políticas. Barcelona: Paidós, 2003.

BUCKINGHAM, D. Crecer en la era de los medios electrónicos. Madrid: Morata, 2002.

BÜHLER-NIEDERBERGER, D. Comment étudier les inégalités sociales comme sociologue de l'enfance. COLLOQUE INTERNATIONAL REPENSER LA JUSTICE DANS LE DOMAINE DE L'EDUCATION ET DE LA FORMATION, 2006, Lyon. Anais... Lyon: INRP, 2006, p. 15-17.

BÜHLER-NIEDERBERGER, D. Introduction: childhood sociology - defining the state of the art and ensuring reflection, Current Sociology [online], v. 58, n. 2, p. 155-164, mar. 2010. DOI: $10.1177 / 0011392109354239$

BÜHLER-NIEDERBERGER，D.; KRIEKEN， R. van. Persisting inequalities: childhood between global influences and local traditions. Childhood [online], v. 15, n. 2, p. 147-155, maio. 2008. DOI: $10.1177 / 0907568207088419$

CICOUREL, A. Teoria e método em pesquisa de campo. In: ZALUAR, A. Desvendando máscaras sociais. Rio de Janeiro: Francisco Alves, 1980. p. 87-121.

COHN, C. Antropologia da criança. Rio de Janeiro: Jorge Zahar, 2005.

27 Importante sublinhar, no entanto, que mesmo este discurso "crítico" não escapa à ação da reflexividade. Isto é, também se compromete na desconstrução/reconstrução do objeto em causa. 
DELALANDE, J. Le concept d'enfant acteur est-il dejá perimé? Reflexions sur des ouvertures possibles pour um concept toujours a questionner. AnthropoChildren, Liege, n. 4, p. 1-8, jan. 2014.

D'HAEYER, A. Enfants sorciers: entre magie et misére. Paris: Labor, 2004.

ELIAS, N. A Sociedade dos indivíduos. Rio de Janeiro: Jorge Zahar, 1994.

FERREIRA, M. Editorial. Revista Educação, Sociedade \& Culturas, Porto, n. 17, p. 3-12, 2002.

FOUCAULT, M. História da sexualidade I: a vontade de saber. Rio de Janeiro: Graal, 1988.

GIDDENS, A. A constituição da sociedade. São Paulo: Martins Fontes, 1989.

GREGORI, M. F. Viração: experiências de meninos nas ruas. São Paulo: Cia. das Letras, 2000.

HARDMAN, C. Can there be an Anthropology of children? Childhood, London, v. 8, n. 4, p. 501-517, 2001.

JAMES, A.; JENKS, C.; PROUT, A. O corpo e a infância. In: KOHAN, W. O.; KENNEDY, D. Filosofia e Infância: Possibilidades de um encontro. 2. ed. Petrópolis: Vozes, 2000. p. $207-$ 238.

JAMES, A.; PROUT, A. A new paradigm for the sociology of childhood? Provenance, promise and problems. In: JAMES, A.; PROUT, A. (Orgs.). Constructing and reconstructing childhood: contemporary issues in the sociological study of childhood. London: The Falmer Press, 1990. p. 7-34.

JENKS, C. Constituindo a criança. Revista Educação, Sociedade \& Culturas, Porto, n. 17, p. 185-216, 2002.

KING, M. The Sociology of childhood as scientific communication: observations from a social systems perspective. Childhood, London, v. 14, n. 2, p. 193-213, maio 2007. DOI: $10.1177 / 0907568207078327$

LANCY, D. F. Unmasking children's agency. AnthropoChildren, Liege, v. 1, n. 2, p. 1-20, out. 2012.

LATOUR, B. Jamais fomos modernos. Rio de Janeiro: 34, 1994.

LATOUR, E. Les Ghettomen - les gangs de rue à Abidjan et San Pedro. Actes de la recherche en sciences sociales, Paris, v. 129, n. 1, p. 68-83, set. 1999. DOI : 10.3406/arss.1999.3306

LUCCHINI, R. La rue n'est pas seulment violente. In: LUCCHINI, R. Enfant de la rue: identité, sociabilité, drogue. Genève: Libraire Droz, 1993, p. 63-158.

MARCHI, R. C. "Crianças espertas": um retrato do "vício da rua" em crianças pobres no centro de Florianópolis. Florianópolis. 1994. 261 f. Dissertação (Mestrado em Antropologia Social) - Universidade Federal de Santa Catarina (UFSC), Florianópolis, 1994. 
MARCHI, R. C. Os sentidos (paradoxais) da infância nas Ciências Sociais: um estudo de sociologia da infância crítica sobre a "não-criança" no Brasil. 2007. 308 f. Tese (Doutorado em Sociologia Política) - Universidade Federal de Santa Catarina (UFSC), Florianópolis, 2007.

MARCHI, R. C. As teorias da socialização e o novo paradigma para os estudos sociais da infância. Educação \& Realidade, Porto Alegre, v. 34, n. 1, p. 227-246, jan./abr. 2009.

MARCHI, R. C. O “ofício de aluno" e o "ofício de criança": articulações entre a sociologia da educação e a sociologia da infância. Revista Portuguesa de Educação, Braga, v. 23, n. 1, p. 183202, 2010.

MOLLO-BOUVIER, S. La Sociologie de l'Enfance: des premiers pas à la crise de croissance. In: SIROTA, R. (Org.). Éléments pour une sociologie de l'enfance. Rennes: P.U.R., 2006. p. $37-$ 40.

MONTANDON, C. Sociologia da Infância: balanço dos trabalhos em língua Inglesa. Cadernos de Pesquisa, São Paulo, n. 112, p. 33-60, mar. 2001. DOI: 10.1590/S0100-15742001000100002

NEIVA-SILVA, L.; KOLLER, S. H. A Rua como contexto de desenvolvimento. In: LORDELO, E. et al. (Orgs.). Infância brasileira e contextos de desenvolvimento. São Paulo/Salvador: Casa do Psicólogo, UFBA, 2002. p. 205-230.

OSWELL, D. The agency of children - from family to global human rights. Cambridge: University Press, 2013.

PARAZELLI, M. Définir les jeunes de la rue? In: PARAZELLI, M. La rue attractive parcours et pratiques identitaires des jeunes de la rue. Québec: Press de l'Université du Québec, 2002.

PINTO, M. A Infância como Construção Social. In: PINTO, M.; SARMENTO, M. J. (Orgs.). As crianças: contextos e identidades. Portugal: Universidade do Minho, Centro de Estudos da Criança, 1997.

PROUT, A. The future of childhood. London: Routledge Falmer, 2005.

PUNCH, S. Cross-world and cross-disciplinary dialogue: a more integrated, global approach to childhood studies. Global studies of childhood [online], v. 6, n. 3, p. 352- 364, ago. 2016. DOI: $10.1177 / 2043610616665033$

QUENTEL, J. C. Penser la différence de l'enfant. Le débat, Paris, v. 132, n. 5, p. 5-26, nov./dez. 2004. DOI : $10.3917 /$ deba.132.0005

ROSEMBERG, F.; FREITAS, R. R. Voix dissonantes sur l'elimination du travail au Bresil. In: SIROTA, R. (Org.). Élements pour une sociologie de l'enfance. Rennes: P.U.R., 2006. p. 185194.

SAMUELSON, T. et al. The active, competent child, capable of autonomous action : an inherent quality or the outcome of a research process? AnthropoChildren, Liege, n. 5, p. 1-19, 2015. 
SARMENTO, M. J. Visibilidade social e estudo da infância. In: VASCONCELOS, V. M. R.; SARMENTO, M. J. (Orgs.). Infância (in)visível. Araraquara: Junqueira \& Marin, 2007. p. 2549.

SARMENTO, M. J. Sociologia da Infância: correntes e confluências. In: SARMENTO, M. J.; GOUVÊA, M. C. (Orgs.). Estudos da infância: educação e práticas sociais. Petrópolis, Rio de Janeiro: Vozes, 2008. p. 17-39.

SARMENTO, M. J. A sociologia da infância e a sociedade contemporânea: desafios conceituais e praxeológicos. In: ENS, R. T.; GARANHANI, M. C. (Orgs.). Sociologia da infância e a formação de professores. Curitiba: Champagnat, 2013. p. 13-46.

SARMENTO, M. J.; MARCHI, R. C. Radicalização da infância na segunda modernidade: para uma Sociologia da infância crítica. Configurações, Braga, n. 4, p. 91-113, 2008. DOI: $10.4000 /$ configuracoes.498

SILVA, G. J. C. A necessidade da vigilância epistemológica em Pierre Bourdieu. Revista Processus de Estudos de Gestão, Jurídicos e Financeiros, Brasília, v. 3, n. 8, p. 1-7, out./dez. 2012.

SIROTA, R. Emergência de uma sociologia da infância: evolução do objeto e do olhar. Cadernos de Pesquisa, São Paulo, n. 112, p. 7-31, mar. 2001. DOI: 10.1590/s010015742001000100001

SIROTA, R. L'enfant acteur ou sujet dans la Sociologie de l'Enfance - évolution des positions théoriques au travers du prisme de la socialisation. In: BERGONNIER-DUPUY, G. (Org.). L'Enfant acteur et/ou sujet au sein de la famille. Paris: Erès, 2005. p. 35-41.

STOECKLIN, D. Enfants des rues en Chine - une exploration sociologique. Paris: Karthala, 2000.

STOECKLIN, D. Das potencialidades de crianças e adolescentes em situação de rua ao desenvolvimento social. In: RIZZINI, I. (Org.). Vida nas ruas: trajetórias evitáveis? Rio de Janeiro: PUC-Rio, 2003. p. 87-122.

VIANNA, A. R. B. O mal que se adivinha: polícia e menoridade no Rio de Janeiro, 1910-1920. Rio de Janeiro: Arquivo Nacional, 1999.

ZAMUDIO, L.; TESSIER, S.; LECOMTE, E. Amérique Latine (compte rendu du groupe de travail). In: TESSIER, S. (Org.). A la recherche des enfants des rues. Paris: Karthala, 2001. p. 214-217. 